\title{
Effect of smoking on serum lipid profile amongst stroke patients: A descriptive study from Dhaka, Bangladesh
}

Habib $\mathrm{N}^{1}$, Rashid $\mathrm{M}^{2}$, Afzal $\mathrm{F}^{3}$, Roy $\mathrm{B}^{4}$, Tahmina $\mathrm{A}^{5}$

*Corresponding author:

${ }^{1}$ Dr.Nasrin Habib MBBS, M.Phil MPH, Senior Lecturer, Department of Physiology, Faculty of Medicine, Quest International University Perak (QIUP) City Campus, No.227, Plaza Teh Teng Seng (Level 2), Jalan Raja Permaisuri Bainun, 30250 Ipoh, Perak Darul Ridzuan, Malaysia.

Email: drnh77@gmail.com ORCID

${ }^{2}$ Dr. Mamunur Rashid MBBS(DMC), FCPS, MRCP(UK) \& HOD, Department Medicine, Faculty of Medicine, Quest International University Perak (QIUP) City Campus, No.227, Plaza Teh Teng Seng (Level 2), Jalan Raja Permaisuri Bainun, 30250 Ipoh, Perak Darul Ridzuan, Malaysia. $\underline{\text { ORCID }}$

${ }^{3}$ Dr. Farzana Afzal, MBBS, MCPS, FCPS, FICO, Junior Consultant, Oculoplasty Department , Ispshani Islamia Eye Institute and Hospital, Dhaka, Bangladesh. ORCID

${ }^{4}$ Dr. Bedanta Roy, Senior Lecturer, Department of Physiology, Faculty of Medicine, Quest International University Perak (QIUP) City Campus, No.227, Plaza Teh Teng Seng (Level 2), Jalan Raja Permaisuri Bainun, 30250 Ipoh, Perak Darul Ridzuan, Malaysia. ORCID

${ }^{5}$ Dr. Tahmina Afrose, MBBS; MPH, Obstetrics \& Gynaecology Department, Faculty of Medicine, AIMST University Semeling 08100; Bedong Kedah; Malaysia ORCID

\section{Information about the article:}

Received: May, 14, 2018

Accepted: Sep 8, 2018

Published online: Oct. 10, 2018

\section{Cite this article:}

Habib N, Rashid M, Afzal F, Roy B, Tahmina A. Effect of smoking on serum lipid profile amongst stroke patients: A descriptive study from Dhaka, Bangladesh. Journal of Biomedical Sciences. 2017;4(2):11-15

\section{Publisher}

Nepal Health Research and Welfare Society, Jorpati, Kathmandu, Nepal

eISSN 2382-5545

(C) The Author(s). 2018

Content licensing: CC BY 4.0

\begin{abstract}
Background

Stroke causes death and disability, has an emotional and economic impact on patients, families, and society. The present study was undertaken to compare the serum lipids levels in adult male smokers and nonsmoker stroke patients.
\end{abstract}

\section{Material and methods}

The participants were selected from indoor medicine units of Dhaka Medical College and Hospital, Dhaka, Bangladesh. A total number of 105 stroke patients age $>20$ years were selected, of whom, 30 were non-smokers and 75 were smokers.

\section{Results}

TC, TG, LDL-C is significantly higher in the smoker stroke patients comparing non-smokers. Serum HDL is significantly higher in non-smokers.

\section{Conclusion}

Serum lipid profile is altered in smokers, which increases the risk of stroke and other cardiovascular disorders, so intense awareness program about adverse health events of smoking should be considered by all means including the social media campaign and implementation of its importance to the curriculum.

\section{Keywords}

Dhaka, patients, serum lipid, smoker, stroke 


\section{Introduction}

Stroke causes death and disability, has an emotional and economic impact on patients, families, and society. The present study was undertaken to compare the serum lipids levels in adult male smokers and nonsmoker stroke patients. It is the major cause of hospitalization; prolong disability and mortality in many populations. It is estimated that stroke affects 33 million individuals worldwide each year and developing countries are the hotspot; comprising twothirds of it. [1] Smoking is a leading cause of coronary heart disorders, atherosclerosis, and stroke. Smoking changes rate pressure product (RPP), heart rate and alters lipid profile. [2, 3] Beedis are especially popular amongst rural and lower income group. In June 2005, the anti-smoking law was launched in Bangladesh. In spite of that, smoking is a common problem and a major health problem associated with morbidity and mortality. Plasma lipoprotein metabolism is strongly influenced by cigarette smoking. [4] Smoking increases serum cholesterol, triglycerides (TG), very low density lipoprotein cholesterol (VLDL), and low density lipoprotein cholesterol (LDL-C) and lower serum concentrations of high density lipoprotein cholesterol (HDL-C) and apolipoprotein AI as compared to nonsmokers. Increased serum cholesterol in smokers increases the risk by $9 \%$. Furthermore, the dose-response effect of smoking on serum cholesterol concentration suggests a gradient of increased absolute risk of coronary artery disease between light and heavy smokers. [5] smoking causes oxidation of LDL particles, increases triglycerides and a decrease of HDL-C, mostly due to HDL, subfraction diminution. [6] Cigarette smoking also causes reduced circulation by narrowing the blood vessels and development of a peripheral vascular disease.

The present study was undertaken to compare the serum lipids levels in adult male smokers and nonsmoker stroke patients in a tertiary care hospital in Bangladesh.

\section{Material and methods Study Period}

The present study was undertaken in the Dhaka Medical College and Hospital, Dhaka, Bangladesh, during the period of $2012-2014$.

\section{Study design and the participants}

Patients from indoor medicine units of Dhaka Medical College and Hospital, Dhaka, Bangladesh were selected for this study. A total number of 105 stroke patients age $>20$ years were divided into two groups; group A consisting of 30 non-smokers and group B, 75 smokers (smoking $>5$ years). Smoking history was recorded on a data collection sheet. Prior to the experiment, the aims and objectives were explained to the subjects. Written consent was taken from each of the participants. A detailed history of each subject including smoking history was obtained by using a pretested questionnaire.

\section{Response Rate}

Out of 120 participants, 105 were selected by interview and filled the questionnaire correctly giving an overall response rate of $87.5 \%$

\section{Questionnaire design}

A questionnaire was developed to collect the sociodemographic details and smoking habit by consulting a panel of experts in the relevant field, Dhaka Medical College and Hospital. Unique study identification number was used to maintain the confidentiality.

\section{Data collection}

Serum lipids samples were collected after a fasting period of 10-14 hours were sent to the clinical laboratory of Dhaka Medical College and Hospital, Dhaka, Bangladesh. Serum total cholesterol and triglyceride were assayed enzymatically, using a cholesterol kit. Cholesterol Reagent was used to measure cholesterol concentration by a timedendpoint method. [7] LDL cholesterol in serum was measured with a kit by a homogeneous method. [8]

HDL cholesterol in serum was measured with a diagnostic test kit by enzymatic clearance assay. The triglycerides in serum were measured with a triglycerides Group Policy (GPO) reagent kit. Triglycerides GPO reagent was used to measure the triglycerides concentration by a timed-endpoint method. [9]

\section{Inclusion criteria}

Adult male stroke patients, age over 20 years and smoking ten or more cigarettes per day for more than 5 years were included in the study. Smokeless tobacco (any form) users for more than 5 years also set up as inclusion criteria.

\section{Exclusion criteria}

Individuals who were unable to give history properly or no responsible attendant was found, were excluded. Patient with history of head injury, intra cerebral space occupying lesion were set up as exclusion criteria. Alcoholics were also excluded to avoid study bias.

\section{Sample size calculation}

In a pilot study done prior to the original study showed the

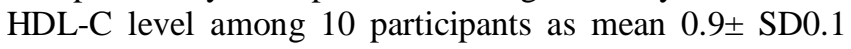
[smokers], $0.7 \pm 0.03$ [non- smokers]. Required sample size was 10 for smokers and 20 for the non-smokers, but we had taken 30 and 75. [10]

\section{Outcome variable}

Outcome variables were serum lipid profile parameters total cholesterol, triglyceride LDL-C, and HDL-C.

\section{Explanatory variables}

The demographic factors were defined at the individual level. Factors at individual level were age, gender etc. 


\section{Ethical committee approval}

The present study was approved by the Institutional ethical committee. Informed consent was obtained from the participants. This research is performed in accordance with the latest version of the Declaration of Helsinki.

\section{Data management and statistical analysis}

Collected data were checked, verified, for consistency to reduce error. Data were analyzed by Statistical Package for the Social Sciences (SPSS) for Windows Version 17.0 (SPSS Inc; Chicago, IL, USA). Student's t-test was performed to examine the association between different variables. $\mathrm{P}<0.05$ is considered as statistically significant.

\section{Results}

In the present study, most of the subjects smoked the cigarette $(97.3 \%)$ followed by Beedi (2.7\%). Mean duration of smoking was $13.01 \pm 6.52$ years. Mean per day smoked was $14.59 \pm 6.87$ SD sticks.

The age of smoker stroke patient was $62.61 \pm 15.803$ years (mean $\pm \mathrm{SD}$ ). According to the residence, urban (53.3\%), rural (20.0\%) and slum (26.7\%). The level of education was primary $(28.0 \%)$, secondary $(40.0 \%)$, higher education (20.0\%), illiterate (5.3\%), others (6.7\%). The major occupations were business (12.0\%), labour (12.0\%), farmer (53.3\%), housewife (1.3\%) and service (21.3\%). Amongst the smokers, $97.3 \%$ consumed cigarette, remaining $2.7 \%$ consumed beedi.

\begin{tabular}{|c|c|c|c|c|}
\hline & $\begin{array}{c}\text { Total } \\
\text { cholesterol }\end{array}$ & Triglyceride & LDL-C & HDL-C \\
\hline $\begin{array}{l}\text { Group A } \\
\text { (Nonsmoker) } \\
\mathrm{N}=30\end{array}$ & $5.201 \pm 0.52$ & $0.621 \pm 0.11$ & $2.4137 \pm 0.31$ & $0.9713 \pm 0.11$ \\
\hline $\begin{array}{l}\text { Group B } \\
\text { (Smoker) } \\
\mathrm{N}=75\end{array}$ & $7.21 \pm 1.43$ & $3.7532 \pm 1.35$ & $4.065 \pm 0.13$ & $0.7065 \pm 0.03$ \\
\hline P Value & $0.020^{*}$ & $0.002^{\dagger}$ & $0.001^{\dagger}$ & $0.002^{\dagger}$ \\
\hline
\end{tabular}

Table 1 expedites that TC, TG and LDL C is significantly higher in the smoker stroke patients comparing non smokers. Serum HDL is significantly higher in non smokers.

\section{Discussion}

Smoking is considered as a major risk factor for SAH (Subarachnoid Hemorrhage) with a relative risk about 3 and for cerebral infarction relative risk about 2.0. Sustained risk of stroke is observed even after quitting smoking habit and passive smokers are worst affected. [11, 12]

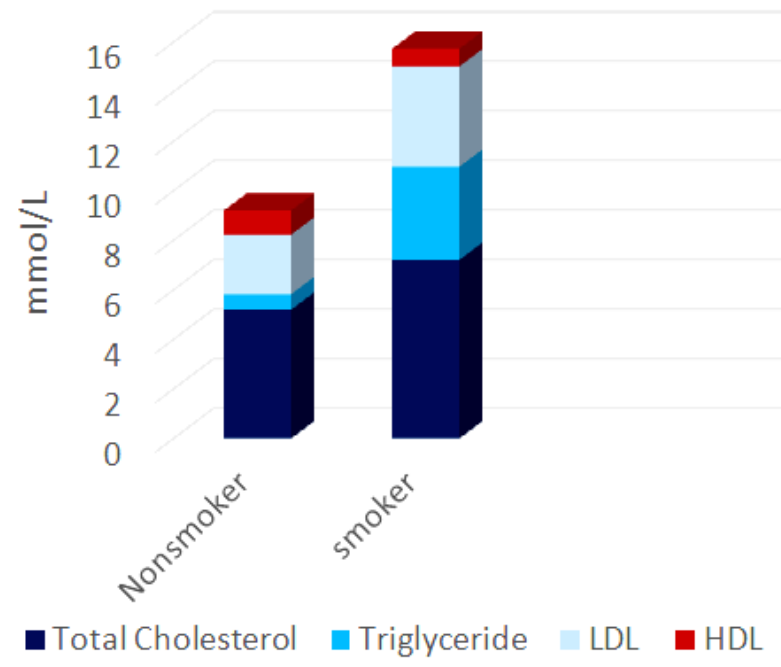

Figure 1: lipid profile among smokers and non smokers

In the present study, we found that smokers had a significantly higher level of serum total cholesterol, triglyceride and LDL-C level and significantly lower HDLC level compared with nonsmokers. These changes may be due to the absorption of nicotine causing lipolysis and release of free fatty acids (FFA) into the bloodstream. This pathway involves activation of adenyl cyclase in adipose tissue and secretion of catecholamines, mainly due to nicotine stimulation. These increased FFA in liver give rise to increased hepatic Triglyceride and VLDL synthesis, thus increasing the concentration of Triglyceride and VLDL-C in blood and hence increased TGL. [13] Our findings corroborate with the previous researchers, where smoking causes a decrease of HDL-C levels and an increase of total cholesterol, triglyceride, and LDL-C levels. [4,14, 15] People with high blood cholesterol have and increased risk for stroke. Also, it appears that low HDL-C is a potential risk factor for stroke in men. [11]

Cigarette smoking is a leading cause of inflammation, thrombosis, and oxidation of LDL. [16] We found that LDL levels were more than the desired level in both types of stroke, similar with earlier works by Dey et al. [17]

\section{Conclusion}

Abnormalities in lipid profile are directly correlated with smoking in this study. Further studies are required to establish the comparison of other biochemical parameters. So our research outcome is a clear message for the policymakers to amend a firm law to prohibit smoking in the public places, to reduce the passive smokers in the community. Intense awareness program needs to be implemented through all means including the social media campaign and the implementation of its importance to the curriculum. 


\section{Abbreviations}

Free fatty acids (FFA), high density lipoprotein cholesterol (HDL-C), low density lipoprotein cholesterol (LDL-C), triglycerides (TG), very low density lipoprotein cholesterol (VLDL)

\section{Acknowledgments}

Authors are thankful to the patients for their cooperation and the hospital authority for giving permission to conduct this research.

\section{Authors' contribution}

Conceptualization was done by NH, MR, FA, BR and AT. Data curation was done by NH, MR, FA and AT. NH, MR, FA, BR, AT did the formal analysis. Investigation was done by NH, MR, FA and AT. Methodology by NH, MR, FA and AT. Project administration by NH, MR, BR, FA and AT. Resources by NH, MR, FA, BR, AT.

\section{Competing interests}

The authors declare no conflicts of interest.

\section{Limitations \& future scope of the study}

The present study was confined to males and they were belonging from same geographical area.

\section{Publisher's Note}

NHRWS remains neutral with regard to jurisdictional claims in published maps and institutional affiliations.

The publisher shall not be legally responsible for any types of loss, actions, claims, proceedings, demand or costs or damages whatsoever or howsoever caused arising directly or indirectly in connection with or arising out of the use of this material.

\section{References}

1. Mozaffarian D, Benjamin EJ, Go AS, Arnett DK, Blaha MJ, Cushman M, et al. Executive summary: heart disease and stroke statistics 2015 update: a report from the American Heart Association. Circulation. 2015;131:434-41.

DOI:

https://doi.org/10.1161/CIR.0000000000000157

2. Kamath MG, Kamath A, Naidu T, Rao AM, Izwan A, Norsyikin CW. Influence of cigarette smoking in the rate pressure product among young adults: a case control study from Manipal, India. Medical Science. 2015;3(4):293-9.

DOI: https://doi.org/10.29387/ms.2015.3.4.293$\underline{299}$
3. Chandra A, Raza T, Singh P, Mahdi F. Inflammatory markers and cardiovascular risk factors in prehypertensive subjects-a hospital based study from Lucknow, Uttar Pradesh, India. Medical Science. 2015; 3(3): 250-257.

DOI: https://doi.org/10.29387/ms.2015.3.3.250$\underline{257}$

4. Freeman DJ, Griffin BA, Murray E, Lindsay GM, Gaffney D, Packard CJ et al. Smoking and plasma lipoproteins in man: effects on low density lipoprotein cholesterol levels and high density lipoprotein subfraction distribution.Eur J Clin Invest. 1993 Oct; 23: 630-40.

DOI: $\quad$ https://doi.org/10.1111/j.13652362.1993.tb00724.x

5. Craig WY, Palomaki GE, Haddow JE. Cigarette smoking and serum lipid and lipoprotein concentrations: an analysis of published data. BMJ. 1989 March 25; 298(6676): 784-788.

DOI: https://doi.org/10.1136/bmj.298.6676.784

6. Lepsanović L, Brkljac O, Lepsanović L. Effect of smoking on lipoprotein metabolism.Med Pregl. 2001 Sep-Oct; 54: 453-8.

7. Allain CC, Poon LS, Chan CS, Richmond W, Fu PC. Enzymatic determination of total serum cholesterol. Clin Chem. 1974;20:470-475.

8. Nakamura M, Taniguti $\mathrm{Y}$, Yamamoto M, Hino $\mathrm{K}$, Manabe M. Homogenous assay of serum LDL-cholesterol on an auto analyzer. Clin Chem. 1997;43:S260-S261.

9. Bucolo G, David H. Quantitative determination of serum triglycerides by the use of enzymes. Clin Chem. 1973;19:476-482.

10. Sathian B, Sreedharan J, Banerjee I, Roy B. Simple sample size calculator for medical research: a necessary tool for the researchers. Medical Science. 2014; 2(3): 141-44.

DOI: https://doi.org/10.29387/ms.2014.2.3.141144

11. Mac Mohon S, Peto R, Cutler J, Collins R. Blood Pressure, stroke \& coronary heart disease Part 1, prolonged differences in blood pressure prospective observational studies corrected for the regression dilution bias. Lancet 1990; 335: 765-74. DOI:

https://doi.org/10.1016/0140-6736(90)90878-9

12. Dou R, Peto R, Wheatley K, Gray R, Sutherland I. Mortality in relation to smoking: 40 years observation on male British doctors. BrmedJ 1994, 309:901-11.

DOI: https://doi.org/10.1136/bmj.309.6959.901

13. Muscat J, Harris R, Haley N, Wynder E: Cigarette smoking and plasma cholesterol. Am Heart J. 1991, 121: 141-147. 
DOI:

https://doi.org/10.1016/00028703(91)90967-M

14. Henkin L, Zaccaro D, Haffner S, et al. Cigarette smoking, environmental tobacco smoke exposure and insulin sensitivity: the Insulin Resistance Atherosclerosis Study. Ann Epidemiol 1999;9:290-6.

DOI: $\quad$ https://doi.org/10.1016/S10472797(99)00003-4

15. Batic-Mujanovic O, Beganlic A, Salihefendic N, Pranjic N, Kusljugic Z. Influence of smoking on serum lipid and lipoprotein levels among family medicine patients.Med Arh. 2008; 62: 264-7.

16. Ambrose JA, Barua RS (2004) The pathophysiology of cigarette smoking and cardiovascular disease: an update. J Am CollCardiol 43: 1731-1737.

DOI: https://doi.org/10.1016/j.jacc.2003.12.047

17. Dey SK, Ahmed S, Rahman KM, Uddin MJ, Alam MR. Lipid profile among ischemic and haemorrhagic stroke patients; Mymensingh Med J. 2010 Apr;19(2):176-80. 